\author{
Cracow Indological Studies \\ Vol. XXIII, No. 2 (2021), pp. 91-118 \\ https://doi.org/ 10.12797/CIS.23.2021.02.04
}

\begin{abstract}
Anne Murphy (D)
anne.murphy@ubc.ca

(University of British Columbia, Canada)
\end{abstract}

\title{
Modern Punjabi Literature and the Spectre of Sectarian Histories
}

\begin{abstract}
This essay explores two instances in the modern Punjabi literary engagement with the past, to consider the ways the writing of Sikh history has been configured as a modern literary construct. After brief consideration of the canonical work Sundarī by Bhai Vir Singh (1898), I consider a novel by Kartar Singh Duggal Nānak nām chaṛhdi kalā (1989, "Blessed are those who Remember God") to examine the legacies of the formulation of Sikh history operating in Vir Singh's work. In doing so, I also consider the ways exclusionary and plural discourses coexist and comingle, to understand the multivalent nature of such representations, which cannot be assumed to express singular political affiliations and therefore reflect the complexity of Sikh articulations within colonial and postcolonial political fields.
\end{abstract}

KEYWORDS: Sikh history, Kartar Singh Duggal, Bhai Vir Singh, historical representation, Punjabi

The past has been a domain for renewal, response, and reconstruction for modern Punjabi writers, as it has been for modern South Asian literature in general, as the essays in this special issue demonstrate. The very designation of the modern is of course a temporal one, and as such it 
relies upon a very particular relationship to the past. The "new time" of modernity - as the German term for "modernity," Neuzeit, suggestsrepresents a new kind of temporality and sense of rupture with the past. ${ }^{1}$ To be modern, then, is to be constituted by a relationship to time, and the reckoning of a "new" present and future in such terms is grounded in a representation and understanding of the past. This essay will explore two particular instances in the modern Punjabi literary engagement with the past, to consider the ways the writing of Sikh history has been configured as a modern literary construct, and what such a configuration of the past both enables and occludes. Specifically, I explore how exclusionary discourses coexist with more open possibilities, to understand the multivalent nature of such representations, which cannot be assumed to express singular or monolithic positions. In this, these representations reflect the broader complexity of Sikh articulations within colonial and postcolonial cultural fields.

\section{The past and its place in an early modern Punjabi novel}

We open here with brief discussion of an argument I have made elsewhere regarding the ways in which Bhai Vir Singh (1872-1957), an extraordinary literary and cultural figure who fundamentally shaped both theological and modern Punjabi literary traditions, constructed the past. ${ }^{2} \mathrm{He}$ is of particular interest not only because of his stature and influence - which are both considerable - but also because of his vision of Sikhism as a religion, and as a historical process. Bhai Vir Singh was active in and founder of the Khalsa Tract Society in 1893, which produced an array of largely didactic texts, and the year before that founder of the Wazìr-e-hind press and after it, the Khālsā

1 See Koselleck 1985. I have discussed this nature of the modern and its intersections with South Asian cultural formations in Murphy 2011.

2 The first section of this essay, on Bhai Vir Singh, is drawn from Murphy 2012: 127-148. On Bhai Vir Singh overall, see Malhotra and Murphy 2020. 
samācār (or, "Khalsa News") newspaper. ${ }^{3}$ He is also widely regarded as a founding figure for modern Punjabi literature as a whole. In this way, he is much like Bharatendu Harishchandra of Banaras, a prominent Hindi-language author commonly regarded as a founding father of modern Hindi literature, and a major defining voice in the framing of Hindu interests in the first half of the $19^{\text {th }}$ century. While Bhai Vir Singh is generally seen as quintessentially modern, particularly in literary terms, like Harishchandra, he is also perceived to be traditionalist because of his religious and communitarian commitments (Dalmia 1999: 49; see discussion Murphy 2012: 133-4). This conflation of the "modern" and "traditional" in Bhai Vir Singh's work, however, is less of a contradiction than might appear. Bhai Vir Singh's Sikhism was very much modern, as Arvind Mandair has shown, and his vision of the Sikh past was no less so, as I have discussed at length in already published work. ${ }^{4}$

Sundarī (1898), Bhai Vir Singh's first novel, is generally regarded as the first modern Punjabi novel. ${ }^{5}$ Though longer than most tract literature, the novel is typical in many ways of such work of the period, and was indeed originally published serially in that form. As Anshu Malhotra has vividly shown, the tract literature of the period was highly regulatory in its approach to women, seeking to set up almost-impossible ideals, and then chastising women for not fulfilling them (Malhotra 2002: 116-163). This reformist mindset is not surprising: many early novels in Indian vernaculars were written for women, who were the main audience, as Meenakshi Mukherjee (2006: 630) has argued. The novel tells the story of a young woman who is abducted by a Mughal official at the time of her muklāvā, when she leaves home to commence married life. She is saved by her Sikh brother, and then decides to dedicate her life to

$3 \quad$ See Khosla 1984, Guleria 1985.

4 On the impact of Bhai Vir Singh on the development of Sikh theology as a modern discourse, see Mandair 2005; Murphy 2012: 127-148.

5 The 2003 Bhai Vir Singh Sahit Sadan edition is referred to here. All translations are mine. 
the Sikh way. Her life and her dedication to the Sikh path constitute the central thematic of the novel. It is fiction, but through it, Bhai Vir Singh also tells a history. Or rather histories - there are multiple historical imaginaries at work in the novel: the history of the Khalsa, of the nation, of the people or praja.

In considering a parallel case just decades before Sundarī was published, Sudipta Kaviraj has noted of Bengali historians of the colonial period that "[i]f judged in rationalistic terms, their efforts often fell far short of the European ideal of constructing a reliable account of the people's past; in some other ways, in giving an imaginative unity to it, it went far beyond" (Kaviraj 1998: 108). Bhai Vir Singh's Sundarī makes a similar fractured achievement, forged within the power differentials of the British Raj. Sundari, then, is an imaginary history; and it is in this form that it stands alongside the other works in Bhai Vir Singh's oeuvre: works of textual criticism, and (importantly for our purposes here) historical inquiry. His poetic work, as I am exploring in current text, must be considered in a different vein, albeit one linked to his preoccupation with the past in prose (Murphy, forthcoming a). Parallels can be made with Bengali writers of the same period, as highlighted by Kaviraj: those who undertake both academic and imaginative history (Kaviraj 1998: 111). Thus Bankimchandra Chattopadhyay's call in 1880 that "we must have a history" is echoed quickly by Bhai Vir Singh's similar statement in 1898. Analogies are also clear in formal terms: the persistence of the first-person voice and theatrical conventions in Bengali novels in the same period, Partha Chatterjee has argued, shows how authors "found it necessary to escape as often as possible the rigidities of that prose." ${ }^{6}$ Such moments of transgression in the voice

6 Partha Chatterjee, on the call to history, 1993: 76; on the narrative elements of novels, see 1993: 8. It must also be noted that Bhai Vir Singh is less strident in this call for historical awareness in later work, such as Satwant Kaur-which is far more concerned with defining Sikh belief and practice - but that story too is located in the $18^{\text {th }}$ century. (Bhai Vir Singh, Satwant Kaur 1968 [1918]). This call to history, and its grounding in the $18^{\text {th }}$ century, is very particular to the late $19^{\text {th }}$ century. On the $18^{\text {th }}$ century and its importance in modern Sikh discourse, see: McLeod 2000. 
of the author allow us to become conscious of the writer as its creator, his intervention in the past's creation in imaginary terms.

Such history writing was effective on multiple levels, where, as Partha Chatterjee has pointed out: "the power to represent oneself is nothing other than political power itself" (Chatterjee 1993: 76). ${ }^{7}$ As was the case for Bankimchandra Chattopadhyay, this reclamation of history is worked out in the pre-British past. Bankimchandra and other historians of Bengal made a clear equivalence between British and Muslim rule, defining the identity of rulers in relation to their right to rule. There are some clear commonalities between this and Bhai Vir Singh's understanding of the Sikh past. But while Bhai Vir Singh also locates his exploration of political and personal ideals in the pre-British past, in relation to Muslim rulers, the articulation of his history, I believe, is also somewhat different. This is a key point that I want to emphasize, out of the argument I made earlier in the context of a broader exploration of Sikh representations of the past (Murphy 2012): that there are elements of conventional communitarian mobilizations of the past within the mode of engagement seen in Bhai Vir Singh's work, but there is also more than that. This representation of the past, then, provides for slippage and contradiction, and is multivocal.

Bhai Vir Singh situates his engagement with the present through the representation of an idealized past. He argues that the violence and suffering of the past shape the present, and that is why it must be remembered. Sikhs are to be faulted for not doing this, he argues: "The other races of the world have made whatever they perceive of their beneficence into Mount Meru, and made memorials of them, but praise to the Sikhs, who have paid no mind to [their own] mountain-like selfless service and have paid no mind to their own history." ${ }^{8}$ Historical

7 Chatterjee refers to Chattopadhyay's cry for history here as well.

8 “... jagat dīāṃ hor kaumāṃ ne āpṇe vaḍ̣iāṃ de rāī jinne upakār bī merū karke manne te yadgārāṃ baṇāiāṃ, par dhann dhann sikkh jinnhāṃ ne parbatāṃ jiḍ̣̣e upakār cete bī nahīṃ rakkhe, sagom āpṇā itihās bī nahịm sạ̣bhāliā" (Vir Singh 2003: 73). 
references come to dominate the novel at points. ${ }^{9}$ Bhai Vir Singh utilizes description of historical moments of persecution of the Sikhs as a counterpoint to the resilient dignity and honor of the Singhs, the members of the Khalsa who fight for justice throughout, as he portrays them in the novel. As such, he delineates the utopia of the past and defines what community is, and how good government is constituted, for the present:

The comparison of the wise discussion and thoughts and arguments at this time is impossible. All the wisdom that the daily needs and pains had taught to the Sikhs at that time, and that life which the model of the Guru had filled them with, the happiness of this had made them all true brothers, and taught them action and intellect. ${ }^{10}$

The multiple references to good government constitute one of the most important ways this novel relates to a larger colonial literature. The notion of prajā or 'the people' and the right to govern are explicitly identified, and are part of a larger South Asian imaginary in the colonial period in which the conditions of possibility for the construction of the nation are found. ${ }^{11}$ The des or country is also defined and described. Both are linked to the idea of good governance, where the past operates to critique the present. It is in the formulation of the des or country in relation to this notion of good government that one can see strong parallels between Bhai Vir Singh and the literature of the nation as expressed

9 Bhai Vir Singh extensively refers to the work of Rattan Singh Bhangu and in the later chapters of the book, there are direct quotations from his work (see e.g., chapter 13); he also quotes from the Guru Granth Sahib, or Sikh scripture, but less extensively. See ibid.: 59 .

10 “is vele jo vicārāṃ ar dalîlāṃ te dānāî dī bahis hoi us dī upamā nahīṃ ho sakdī. nitt dīāṃ loṛāṃ te dukhāṃ ne jo akal us vele sikkhāṃ nūṃ sikhāî sī te jo jān unhāṃ vic gur ādarsh ne bharī sī, us dā hulsāu unhāṃ nūṃ sakke vīr baṇā ke amalī, akalāṃ sikhāldā ș̄” (ibid.: 61).

11 The theme of the praja and how the people are treated at the hands of unjust ruler is a concern of Satwant Kaur as well. See e.g. Vir Singh 1968: 17. 
in Bankimchandra Chattopadhyay. Discussion of the des takes several forms. It is first mentioned and discussed in the novel when a Khatri character is describing the loss of his wife and property:

What is this sin, because of which such calamity falls upon our country? Why is there such misfortune of our brothers? ... Why do the rishis and sages not return? Oh Shiva! Oh Vishnu! The gods are unhappy, return!... What is this calamity? Why is there no destruction of the foreigners (mlechās)? Why [are we] not spared this violence? ${ }^{12}$

These lines, in exchange with the central character, Sundarī, make clear that the current situation is the result of bad action, the abandoning of real service of God and a lack of unity.

At times, the novel's vision - and the nation/des and people/praja it constructs imaginatively - is sectarian. There is certainly the portrayal of what might be termed, in Chattopadhyay's terms, "Muslim oppression," a feature that Chatterjee argues has contributed to how "the materials of Hindu-extremist political rhetoric current in postcolonial India were fashioned from the very birth of nationalist historiography" (Chatterjee 1993: 94). Christine Fair (2010: 124-125) has therefore emphasized the ways this novel, like other novels by Bhai Vir Singh, sets up boundaries between communities, although she notes that these boundaries are not always static. For example, a Muslim leader is incensed that the Sikhs have been fed by local people, where the Khalsa is described as being the ruler, or pādshāh; such behavior has an explicit relationship with sovereignty. As a result, the Muslim Sardar, as he is called, has the villagers beaten, causing the deaths of several Hindus. This is done "without asking, without proof of guilt"

12 "uh kī pāp hai jis kar ke sāḍe des ute iḍdā kahir ho rihā hai? kium sāḍe bhā dī kaṃbakhtī ā rahī hai? ... rikhī munī kiuṃ nahīṃ bahựde? he shiv! he vishnu! devate dukhī han, bahựo! ... ih kī kahir vart giā? malechāṃ dā nāsh kium nahīṃ huṃdā? ih upaddar kiuṃ nahiṃ țaldā?” (Vir Singh 2003: 27). 
(nā koì pucch nā gicch, nā dos sabüt kìtā). The husband of one woman is killed in this assault; she is then captured to be forced into remarriage. She is killed after daring to strike her captor (Vir Singh 2003: 18). Such easy portrayals of the tyranny of rulers of that time-identified as Muslim - continue in the text. There are other distinctions clearly delineated, regarding Hindus and their characteristics. Brahmins are oppressed, forced into vagārī naukrī or forced labor (ibid.: 13). Hindus are consistently portrayed as weak: him ūu tām makkhan, par ih patthar han, "Hindus are butter but these [Sikhs] are rocks." Shopkeepers are defined as being without energy and sad (nimāne, sust, udās, ibid.). There are other examples.

On the other hand, there are places where Bhai Vir Singh is more careful in his portrayal of Hindus and Muslims, to distinguish between Muslims as a group of people and Muslims as rulers, and to define Muslims as being within the prajā or people of the nation. These moments of a more capacious vision are important to note. He describes, for example, the response of the members of the village to Saraswati's abduction: "What Hindu, what Muslim, they all bit their fingers and proclaimed, what injustice, this misfortune" (ki him $d \bar{u} k \bar{\imath}$ musalmān ugalām tuk tuk rahi gae, 'hāi haner' ih anarth, ibid.: 5). He describes those who have a grievance against a particular nawab, as "[w]hichever oppressed Hindu and whatever poor Muslim who cried after having been wronged by a Turk" (jis jis mazlüm himdū ne te kō garīb musalmānām ne vī āpne dukh kise turak valom roe). Two women are portrayed as coming before the Singhs for justice: an elderly Hindu woman who calls them "God-sent padshah" (rabb de ghalle hoe pātshāh) and a young Muslim woman with children, whose husband was wrongly killed by the nawab, who exclaims that "[y]ou look like someone to break the heads of the tyrants, please make efforts for one as unhappy as me" (tūm jarvāniāạn dā sir-bhann jāpdā hai, kujh maim dukhiārì dā bhì uparāala kar, ibid.: 33-34). The leader of the Khalsa force, Sham Singh, elaborates his position when it is assumed that the Sikhs are against the Muslims, as Muslims. He says: 
We have no enmity with the Turks or Pathans on account of their being Muslim and do not oppose their rule because of it. The reason we destroy the rule of the Mughals is that, having become rulers, they give grief to the people, they are not just. Taking bribes, they destroy people, and they cause innocent, sinless people to be killed; they take their tax and do not protect the people. ...We have no enmity with any caste or way of thought. Our Gurus came to spread religion, and we stand by his words, and so in the name of true religion, we destroy those people who cause adharm [that which is against dharm] and give grief to the people of the Timeless Being. ${ }^{13}$

Here Sham Singh articulates clearly the Sikh position, not against Muslims, but against mis-rule. The Sikhs act as guarantors of justice in the political tumult of the early to mid- $18^{\text {th }}$ century during the decline of the formal structures of Mughal rule, and the development of successor powers within Punjab and its environs.

There are therefore places in the novel where "hard" logics operate regarding religious and community definitions, as well as articulations of a more capacious and inclusive view. The novel itself, then, reflects multiple positions on inclusion and exclusion (in the des and the prajāa), multiple discourses of identity and difference. Surjit Singh Dulai has argued that "the very birth of the novel in Panjabi was the result of political causes;" the nature of the novel in the West, the Western "impact on India," and "the attitude of the British towards the Sikhs and other communities" contributed to its highly politicized nature (Dulai 1975: 43). What is striking about this text as a historical document, however, is what it both shares

13 'sāọā turkān nāl ki paṭhāṇān nāl uhnān de musalamāṇ hoṇ pichhe koī vair nahīn te nā hī vair virodh vich pai ke asīn unhān dā rāj guā rahe hān, sạḍa mughalān de rāj nūn nāsh karan dā matlab ih hai ki oh pātshāh ho ke parjā nūn dukh dende han, niāun nahīn karde. vaḍhīān lai lokān dā nāsh karde han, begunāhān te nirdoshiān nūn marwā suṭde han, māmlā lainde han te parjā dī rākhī nahīn karde... kise zāt jāñ mat nāl sānūñ kōi vair nahīn. saḍe satgur dharam phailāvan āe san, so uhnān vākān pur parpakk hān ar sati dharam picche unhān purkhān dā nāsh karde hān், jo adharam karde han ar akāl purakh dī parjā nūn dukhāunde han" (ibid.: 33-34). 
and does not share with roughly contemporary Bengali historians, such as Bankimchandra Chattopadhyay. Whereas for these, as Chatterjee has noted, "the idea of the singularity of national history has inevitably led to a single source of Indian tradition, namely, ancient Hindu civilization," (Chatterjee 1993: 113) Bhai Vir Singh reflects a more contingent position, where the Sikhs are located among other religious communities within the prajā and for whom the past demonstrates political ideas that must be executed in a plural political field, reflecting the complex possibilities of plural Sikh imaginations of the landscape and the people. The ideological formations we see emerging in Bhai Vir Singh are accompanied by more concrete changes that fundamentally shape how the Sikh past comes to be imagined in following decades, and we can see multiple engagements with the past explode in the Punjabi vernacular literary mode. ${ }^{14}$ In Sundarī we see a crossing-over point. The Khalsa operates in this text in a broad, deterritorialized mode, but in a discursive field where the representation of the past is tied to the imagination of a national form - although the shape of that national form is not yet fully clear. This represents a move toward the marriage of the nation and history that we are familiar with from the shape of history around the world. But in Sundarī, that move is incomplete, and the Sikhs inhabit a space outside of the conventional formula for "the people" and "the nation."

\section{Beyond the past: The present as a location for the future's change}

Bhai Vir Singh's novel, for all that seems unique about it, is not unusual in terms of content, approach, or timing, situated comfortably between the poles of "historical novel" and "romantic fantasy" (Mukherjee 2006: 607). Singh was also not unusual in seeking the past to discover a place "where history and imagination could mingle freely" (Mukherjee 2006: 608). It was in that period also entirely normal to infuse women with a "mythical dimension," as historical beings that

14 These dynamics are explored at length in Murphy 2012: 127-132, ch. 6-8. 
embodied an unchanging culture (ibid.). The "heroic" woman figure was also a common trope in the period (Mukherjee 2006: 616); Sundari has many allies and friends, then, in the literary landscape from the end of the $19^{\text {th }}$ century.

I have drawn attention in the past to the parallels between Bhai Vir Singh and Harishchandra Bharatendu. But to understand fully Punjabi's emergence as a modern language, however, it must be considered alongside the emergence of Urdu as a modern vernacular. Indeed, as Carla Petievich (2007: 23) has suggested, the reason that Punjabi language work is not better known is "from the simple fact that it is not Urdu." ${ }^{15}$ As Christine Oesterfheld (Oesterheld 2001: 28) has noted, a figure such as Nazīr Ahmad (1830-1912), credited with an early Urdu novel, "propagated ideals of education and reform in his writings and speeches with a missionary zeal. All his tales were the outcome of this commitment and were shaped accordingly.” This is directly parallel to the narrative scope and approach of Bhai Vir Singh. As with Bhai Vir Singh, Oesterheld argues, his didacticism at times led to the branding of his work as "artistic failure" (ibid.: 33). We also see the same genrecontradictions as we find in Bhai Vir Singh (ibid.: 36-37). Perhaps like Bhai Vir Singh, Ahmad understood "religious instruction as complementary to modern education, not as an alternative to it" (ibid.: 37). In all of the works of this period, then, we see complex commitments both to religion, and to fiction.

The terms set by Bhai Vir Singh in Sundarī and his other works do not by any means define the engagement with the past that is expressed in the modern literary imagination in Punjabi. Before moving forward to consider how this is so, however, it is important to recognize that for Bhai Vir Singh, too, the past was incomplete as a resource for the present. This is visible most strikingly in his poetic works, the most fully modernist of the genres within which he worked (Murphy, forthcoming a).

15 Punjabi and Urdu have a particularly complex relationship given that Urdu was the language chosen for the state under British rule; see Mir 2010. The commonalities that exist in literary terms across the two are due further examination. 
The point to be made here is to recognize the multiplicity of temporalities available to modern Punjabi writers in writing the Punjabi modern, and to complicate our understanding of the uses of the past - and the present-in imagining Punjabi futurities.

\section{The Past in the Progressive}

Modern Punjabi literature from the 1930s onwards, after the early decades of its formation, articulated a progressive agenda; this was the founding vision of the Progressive Writers Association (founded in 1936), with a commitment to critical engagement with and reconstruction of the past and present, towards the production of a new future that would exceed the confines of the present (Gopal 2005: 14). As Kartar Singh Duggal (whose work is discussed at length below) described it, after the Conference of Indian Progressives in Lucknow in 1935, "the old concept of art for art's sake was formally abandoned... [marking] a conscious shift in new writing in Punjabi from the portrayal of the privileged to that of the under-privileged" (Sekhon and Duggal 1992: 117). This was accompanied by new interests in dialects and new literary forms, including narrative fiction, although poetry predominated (and continues to in Pakistan, whereas narrative fiction has a strong place alongside poetry in the Indian Punjab, Mir 2010: 14-15). We can clearly identify such work as "modern," reflective as it was of modern political commitments as well as associated stylistic forms such as realism.

But what of the past, and of history? One of the striking features of the emergent modernist work was, in fact, its concern for the present: an unfiltered and unadulterated view of oppression and hierarchy, and a sense of the minute details of village life. As Priyamvada Gopal has described, "the historical conjuncture from the early 1930s to the years immediately after independence made possible a range of historical tasks or, at the very least, a perception that it would be possible - and necessary - to undertake certain kinds of radical endeavors" (Gopal 2005: 14). This positioned it as a kind of turning- or transformation-point, a particular orientation towards the present that looked 
to the future, grounded in a commitment to change. Jennifer Dubrow sees in progressive writing of this period a broader preoccupation with temporality, and the emergence of alternative temporalities in the early decades of the $20^{\text {th }}$ century in the work of Sadaat Hasan Manto, for example (see Dubrow 2019: 592).

Yet, while the present and its constraints are a central concern of the progressive program, oriented towards a future, Sikh history was also written and rewritten by modernist writers also associated with the progressive project. This is not surprising, given the temporal underpinnings of the modernist project, the ways the problems of the present are conceived of as largely embedded within a past and continuing tradition. We can take as an example of this a series of works by Sant Singh Sekhon (1908-1997), a towering figure in Punjabi literary world. Sekhon was a major critic and historian, as well as writer, who wrote short stories, novels, plays, as well as scholarly work and criticism. Sikh history was the focus of a number of his plays. Available in translation (Gill 2011a) with a helpful introduction by Tejwant Singh Gill (2011b), these plays provide a valuable sense of the terms in which the Sikh past was engaged with: a focus on the tribulations of the Sikhs, and of their triumphs. Sekhon's concern, Gill argues, was with those events that had a "decisive role in the course of Sikh history," with a view of Sikh history as "immanent, secular, and worldly" (Gill 2011b: ix, xxxii). We see thus that Sikh history, therefore, remained a focus of literary attention, a way through which the present was imagined and reconfigured. This could also be done, Gill argues, in secular terms.

Kartar Singh Duggal (1917-2012) was a major figure in the first generation of writers at the time of Partition and the decades after it, and was renowned for his work in the short story form. He produced a trilogy of book-length works entitled Nānak nām charhhdī kalā (1989, "Blessed are those who Remember God"), Tere bhāne (1991, "As Willed by You”), and Sarbat dā bhalā (1992, "The Welfare of All") that took as their scope a comprehensive view of Sikh history (R. Singh forthcoming). He did not abandon his interests in the present; in the same 
period he published his short story collection Painge vain dünghe (1993, "The Deep Dirge Will Sound"), which engaged with the Punjab crisis in the 1980s and 90s and the workings of violence and hierarchy in the contemporary Indian Punjabi landscape.${ }^{16}$ But Sikh history was a major interest as well. What changes can be seen in the configuration of this idea of Sikh history, as we move forward in time? We focus here on the first volume of Duggal's trilogy, which is not available in translation, to give a sense of what is at stake in his portrayal of the past here.

\section{A return to the past, for a changing present}

Duggal's work Nānak nām charhhī kalā (1989, "Blessed are those who Remember God"), the first in the trilogy, is described as a novel, as are the other three. It is structured in four sections, each with 40 small chapters, that in total comprise a linear narrative about a family but which are loosely structured and at times stray quite far from clear linear narrative development. On the first page of the publication, Principal Satibir Singh opened his forward to the work with historical references, both to the early $19^{\text {th }}$-c. text Prāchin painth prakāsh, by Rattan Singh Bhangū, and to the work of M.A. Macauliffe, author of a six-volume introduction to and history of the Sikh religion entitled The Sikh Religion: Its Gurus, Sacred Writings and Authors, and published in 1909 (Macauliffe 1909; Murphy 2017). This was the frame for the publication of Duggal's work. As Duggal notes at the opening of the first volume, "from his side" (apne valon), he had first created a trilogy to explore the history of Punjab, Hāl murìdāin dā (1962, "Plight of of the Disciples"), Mã̀i-pio-jāe (1974, "Born to the Same Parents"), Jal kī piās nā jāi . In these works, "I searched for the shape of Punjab" (main panjāb dī nuhār dì talāsh kitti hai). Then he wrote his own story, as a writer. Then he turned to telling the story of the Sikh Gurus. He did so, he tells us, as a writer, not a historian:

16 See discussion in Murphy, forthcoming b. 
I was born in a Sikh family, a member of the Sikh community... I do not claim to be a historian. Certainly, I am a short story writer. This effort of mine is the story of the distinguishing features of the Sikh faith, in the words of a short-story-writer. ${ }^{17}$

He goes on to assert that he is not telling the history of Sikhism, but that instead he is telling a story that reflects (pratibimbat) that history, as he understood it (Duggal 1989: 7). Every literary work, he tells us, is a writer's search within the writer's self (sāhitakār dī āpne añdare dì talāsh huìdī hai), to understand self, community, and culture (ibid.).

Duggal's approach to the history of Sikhism may be his own, but it reflects larger discourses on Sikh history, and bears striking resemblance both to the exclusionary history outlined above, and to the effort to see the Sikh community within a complex field of relationships with other religious communities. In a striking move, he opens with the movement for a Punjabi $s \bar{u} b \bar{a}$ or state, which was a major focus of Sikh mobilization in the 1950s and early 1960s. The Suba movement emerged alongside other movements in support of linguistic states, which had been the stated program of the Indian National Congress in the pre-partition/ pre-independence period and was advocated for by the Dar Commission in 1948. In 1951, post-partition, Sikhs constituted $35 \%$ of the population of the Indian Punjab at that time, and Hindus at over $62 \%$. Sikhs were concentrated between the Ravi and the Ghaggar, and were a majority in a contiguous area for the first time in PEPSU, the Punjab and East Punjab States Union, comprised of the princely states that were not a part of British India and retained a separate identity the Indian union. By 1956, the Akali Dal, the political party that sought to articulate a Sikh political program, which emerged out of the Gurdwara Reform Movement of the 1920s, demanded the merging of PEPSU with parts of the state of Punjab to comprise a linguistic state. The States Reorganization

17 “sikkh māpiān de ghar jammiā, sikkh bhāīchāre vich pravān chaṛiā... itihāsakār họ̣ dā merā dā'awa nahīn. kahāṇī-lekhak main zarūr hān. ih yatan merā sikkhī dī pachhāṇ dī kahāṇī hai, ik kahāṇī-lekhak dī zabānī” (Duggal 1989: 6). 
Committee, formed in 1953, had failed to provide for such a state, while others were granted; its proposal for a "greater Punjab" out of then current Punjab, Himachal Pradesh and PEPSU was rejected by the Akalis. The Regional Formula that was enacted in 1956 designated Hindi-dominant and Punjabi-dominant areas, with protections for both; Himachal Pradesh was not included. Yet, Punjabi was not fully protected in Hindi-speaking areas, and the compromise broke down (Grewal 1990).

It is this period - before the formation of the Punjabi language state in 1966 - that the book opens with, in its first two chapters. The opening features two lines: rāj kareg $\bar{a} k h \bar{a} l s \bar{a}$, $\bar{a} k \bar{l}$ rahe na koi"the Khalsa will rule, no one else will remain"-and describes them as being sung, day and night, by the Punjabi Suba demonstrators who have been jailed (Duggal 1989: 9). Duggal draws out comparisons with other movements for linguistic states - for Gujarati, for Telugu — which were granted by the post-colonial state. Punjabi's aspirations remained unfulfilled. "The rest of the states were linguistic states, not religious states. The government smelled a Sikh state in the demand for a Punjabi state. And the Sikh leaders had been unable to dispel this suspicion."18

After a fulsome description of a miracle that occurred in response to the demand that workers at the jail not be allowed to smoke, since they were responsible for cooking food for Sikhs for whom smoking is forbidden - a miracle that convinced the jail to accede to this demand-Duggal describes the prisoners reciting verses: three lines from the "Babur-vānī" as they are called, the response of Guru Nanak to the conquest of India by the founding Mughal emperor, Babur:

\section{khurāsān khasmānā kīā, hindustānu darāiā}

àpai dosu na dē kartā, jamu kar mugalu charāiāa

et̄̄ mār pā̄ kurlāne, tain kī daradu na āiā

18 'bākī sūbe zabānān de sūbe ne, dharamān de sūbe nahīn. sikkhān dī pañjābī sūbe dī mañg vich sarkār nūn sikkh sube dī bū āndī e. te sikkhāñ de netā is sañdeh nūn dūr nahīn san kar sake" (Duggal 1989: 10). 
Attacking Khurasan, Hindustan was terrified.

The Creator does not blame, the Mughal has attacked as a messenger of death.

There were cries at so much death, do you not feel pain at this? (SGGS 360)

Through this reference, Duggal enters into a description of the emergence of the Sikh tradition within the context of the narration of the history of South Asia as a series of relentless invasions: "And the images inscribed by the centuries came before the inmates' soaked eyelashes."19 The invasions named are by Muhammd Bin Kasim in 712, Kutab-ud-din in the $13^{\text {th }}$ century, Firoz Shah Khilji, Muhamad Tughluq, Alaudin Khizar, Amir Taimur, and Sikandar Lodhi. Then there is the time of Babur. With this, we reach the time of the composition of these verses by Guru Nanak, and Guru Nanak enters the story as a character in the third chapter, portrayed as one of many imprisoned by Babur's forces, and his voice sings out in imprisonment. His voice is shown to haunt Babur. Then the narrative proceeds with a summary of Guru Nanak's life, key scenes, key incidents, key experiences that comprise the story of the Guru, in the fourth chapter.

With Chapter five, there is a change of scene and characters, set in the same chronological frame. Guru Nanak is referred to through what follows, as a figure to be followed and to guide. We hear the story of Teji, who has been renamed Mumtaz after having been kidnapped and forcibly married, albeit briefly, with an officer in Babur's army, who rapes her. The opening section of 40 small chapters features her story centrally, alongside that of Nasrin, a Muslim woman who also was taken captive by a solider in Babur's forces, "married," and raped. They become friends, realizing their shared experience - they were attacked by the same individual. We meet Nasrin's and Teji's sons, Shaili and Aman, and their stories and of the women that they marry comprise the bulk of the remainder of the volume, though throughout there is

19 "te bañdiān dīān bhij bhij rahīān palakān de sāhmṇe sadīàn de ukare hoe chittar tar rahe san” (ibid.: 14). 
description of the community of believers gathered around the Gurus and major events and individuals are described. Aman becomes very active in community activities and stays close to the Guru, and his letters provide windows into lives and stories in the community and associated with the Guru; at other times, there is description of important Sikhs and their service. ${ }^{20}$ Interpersonal relationships, and intrigue over love, remain at the centre, however. At times, these are mobilized to tell the stories of the Guru (and particularly stories of seva or service), such as how Duggal uses the two women Teji and Nasreen to provide commentary and discussion of what is happening with the Gurus, in chapters 16 and 17 of the first Section. ${ }^{21}$ We weave in and out of the story of the characters throughout. At times there is a lack of connection between these stories and the unfolding of the characters' stories, producing tension between the characters and the more descriptive sections about that time, between representations of the life of the Guru, and the representation of the women's stories. Throughout Duggal references textual traditions in support of his representation of the past of the Guru: the Janam Sakhis are a repeated source, particularly in the first section of the text. ${ }^{22}$ In chapter 15 of the first Section, it is described how the stories of Guru Nanak keep getting told, setting the stage for the repetition of the Janam Sakhis themselves (Duggal 1989: 58). ${ }^{23}$ The novel thus grounds itself in tradition, and provides a portrayal of the production of that tradition.

20 On Aman's letters, see, e.g., Duggal Nānak nām ..., section 2, ch. 6 (157-9), 9 (164-167), and 15 (181-184); and section 3, ch. 9 (290-294). For description of important Sikhs and their actions in service, see Duggal Nānak nām..., section 2, ch. 29, 225-228).

21 For another, later example, conversations between Shaili and Naseem, his beloved who later becomes his wife, provide the context for the narration of stories about Guru Nanak's travels. Duggal, Nānak nām..., section 3, ch. 13, pp. 304-307.

22 For example, see Duggal Nānak nām..., in section 1, ch. 10-13, pp. 42-53; ch. 15 , p. 61 ; ch. 20 , p. 76 .

23 The Mahima Prakash is another source (Duggal Nānak nām..., section 2, ch. 15, p. 181). 
Aman meets a woman named Shakti, whom he falls in love with; later, he meets Sundari, who loves him and eventually becomes his wife. The character of Sundari is striking for its parallels with Bhai Vir Singh's earlier Sundari: she is captured by a Muslim official, who intends to marry her but in the end brings her to the Gurdwara in his town to help save her when she falls ill, because he too is a devotee of Nanak. She is then recovered by Shaili, who has fallen in love with her, but ultimately rejects her because she was in the household of another man for so long, and must have been touched by him, despite her vociferous claims that she was not raped; this is later corroborated by her captor in public, but not until after Sundari is maligned and mistreated by her mother and others. ${ }^{24}$ This theme resonates widely, such as with the figure of Sita as well as Bhai Vir Singh's Sundari. Aman marries Sundari-and had decided to do so when others rejected her, convinced that she was guilty of nothing even if she was attacked - and Shaili eventually marries Naseem, a woman he meets through Shakti. He has a relationship with Naseem before marriage that results in the birth of a child, and only later do they come together as a family. These are the core relationships staked out in the text, and the text-like Bhai Vir Singh's - focuses on women and on their stories and their relationships.

We learn of Teji's fate when she relates her tale to Gujari, after she was freed from her forced marriage, and is pregnant with the child of her attacker. The scale of the attrocities is described in detail: "For some time, the screams that came from each tent were like those of sheep and goats being chopped to bits in a stockyard." 25 With growing urgency, Teji tells her story, promising in the end that her coming child would extract her revenge: "I will make his progeny into a soldier, and next time when he comes, when he attacks this country again, he will settle

24 For example, her mother rejects her entirely at Duggal, Nānak nām..., section 2, ch. 30, p. 231. Her captor, Sher Khan, reveals her purity in Section 2, ch. 40, p. 259. Sundari, who had by then disappeared, reappears at her vindication.

25 "kujh chir te is tarhān dīān chīkhān har tambū vichon à rahīān san jiveñ

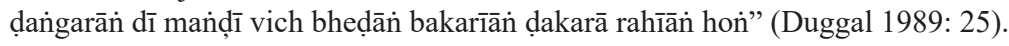


the score, he will take care of all those who would look at our country in a dirty way." 26

I focus on this transition in the narrative, to the story of women, for several reasons. It is notable how Duggal utilizes the character of women here to articulate a nationalizing narrative, visible in the use of the term des ('country' or 'nation') in the quotation above. This is in keeping with the ways the figure of the woman was mobilised, overall, in modern literature in service of the nation, and is parallel, too, to the figure of Sundari in Bhai Vir Singh's influential novel. ${ }^{27}$ The violation of women is here made parallel to the violation of the nation, and revenge is enacted by a woman through her son. This becomes all the more striking early on, as the story progresses, and we see a conversation among Prito (Teji's friend, with whom she was abducted), Teji, and Santi. Prito accepts that her name has become "Nurjahān," and that she has become a Muslim: "A woman's religion is the religion of that of the father of her child," she declares. ${ }^{28}$ Teji asserts that this is not true. She, too, had technically been converted to Islam, but she does not accept this.

Prito then "raises her nose" and criticizes Hindu caste hierarchies: "In a religion where there is a high caste? In a religion where there is a low caste?" 29 Santi responds to say that she is low caste, but that "Even if you tell me to become high caste, I wouldn't abandon my caste. Our caste is the most important thing to us." ${ }^{30}$ Duggal thus justifies caste

26 "main uhd̄̄ aulād nūn sipāhī baṇāñvāngī te agali vār jadon் uh àiā, agal̄i vār jadon unhān is des te hamalā kītā merā bețā unhān de chhakke chhuḍā devegā, unhān ḍihaliān nūn purann chhaḍ̣̣egā jihaṛiāà nazarān sạḍe vatan nūn mailī nazarān nāl vekhṇgīān" (ibid:: 26-27).

27 This is a large literature on this. See discussion of this in the context of Punjabi literature in Anne Murphy, "Progressive politics, gender \& the Punjabi literary through the work of Dalip Kaur Tiwana" Punjabi Centuries, ed. by Anshu Malhotra (forthcoming).

28 "tīvīn dā dharam uhde bacche de piu dā dharam huñdā hai" (Duggal 1989: 28).

29 "jis dharam vich kō̄ ucchī zāt dā hai, jis dharam vicch kō̄ nīch zāt dā e" (ibid.: 29)

30 Lit. "dearer to us than our lives," "mainūn tān āpṇi zāt dā baṇan laī kahe, main tān kadī nā āpṇī zât chhaḍ̣ạn. sānūn tān āpṇi zât jạṇ ton̉ vī piārī e” (ibid.). 
hierarchy through a low caste character-just as patriarchal formations are upheld through women characters. Prito asserts that she is glad to abandon the feeding of brahmins, which impoverished her family. She continues: "In Islam, all are equal. Santi is my sister." ${ }^{31}$ Santi rejects this: "I don't want to become your sister!" 32 and she is described as looking as if she has been slapped. Prito further offers that she would be able to eat from the same plate as Santi — which upper caste Hindus would refuse to do - but Santi rejects this too, saying that she does not want to share her plate with Prito. The chapter ends with Santi's arrival at Teji's home: she has murdered Prito, stabbing her and choking her until her eyeballs popped out of her eyes. ${ }^{33}$ She describes herself thus: "Today, I, a Shudra, have defended my Hindu dharma." ${ }^{34}$ This act is followed by the consumption of $l a d d u$, or sweets.

This is a striking act of violence, here at the opening of the book, with agency placed in a lower caste woman, who acts in protection of being Hindu, within caste hierarchy. The nature of the conversation with Prito/Nurjahān that precedes it makes clear that the act is directly in retaliation for her acceptance of Islam, and her representation of the rule of Babur as being validated by Guru Nanak's blessing. This is represented as a question of loyalty within the coming pages of the narrative. And it is this discussion of the act itself that is worthy of attention. Thinking about this, Teji says to herself: "Certainly Santi was guilty, but Teji was completely in sympathy with her. That which Santi had done, Teji herself understood it to be honorably committed, «this one who wanted to become some kind of great Begum, or upper class woman.» Teji's blood boiled." 35 As the story proceeds, both Teji and Santi are arrested and put in jail; Teji is implicated because Santi

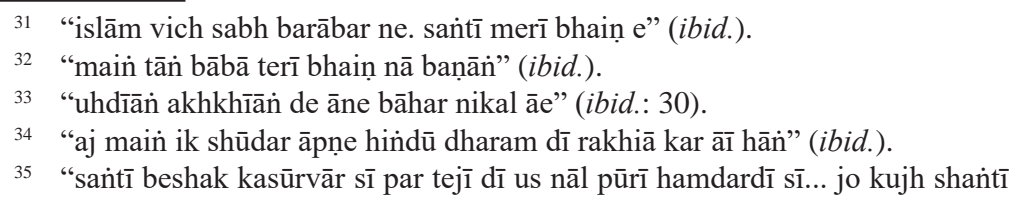
ne kītā sī, uh tejī khud āpṇe āp nūn sarkharū samajhdī «baṛī āì sī 'begam’ baṇan dī chāhvān.» tejī dā khūn khaul khaul paindā” (ibid.: 31). 
left the weapon in Teji's courtyard. When they appear before the court officer, Santi explains why she did it: "The previous evening, Prito had been talking in a big way. She dreamed of becoming a Mughal." ${ }^{36}$ Santi is portrayed as owning this fully, as a lower caste person, and resents the effort Teji makes to share the blame: "These high caste persons are always taking our rights." ${ }^{37}$ This follows a discussion between Teji and Santi where Santi asserts that she is not lower, and that she does not seek to follow higher castes. Guru Nanak is quoted as inspiration for her position. While the Kotwal at the time decides that the evidence could have been planted and lets them both go, Santi continues to declare her commission of the crime and is arrested. Discussion of caste continues: in chapter eight of the first section, in jail, Santi is described as working in the jail just as she worked outside of it. There is no substantive difference in her life (ibid.: 34). The keeper of the jail, a Brahmin named Goswami, falls for her, saying that she must be a Khatriani to have done what she did. A Pathan replaces him in time and he attacks her. She defends herself with her caste "main chūṛhī hān," but the jailor says that there is no such thing as low and high caste among his kind. But this is articulated as a means to continue his abusive behaviour.

I take this example at such length to demonstrate some of the ways in which the text embraces an exclusionary representation of the past, drawn along multiple lines, religious and otherwise. Caste and gender hierarchies are both named, and then occluded, through the mobilization of lower caste characters, and women, in support of patriarchal and caste hierarchies. Marginalized characters are mobilized to undergird social orders of different kinds. Yet, at the same time, the communal, religiously exclusionary narrative, and to a lesser extent the gendered narrative, is also undermined in the text. This seems to be the intent of the author: to offer a reading of the past where Hindus and Muslims are brought together and where religious difference does not prevent shared

36 "pichhlī shām prīto vadhdh-chaṛh ke gallān kar rahī sī. mugalāṇī baṇan de sufane vekh rahī sî̀” (ibid.: 33).

37 “ih uchchīān jātāin vāle har sāọe hakk nūn paṛumm lainde ne” (ibid.). 
experiences and emotional ties; women are at the centre of the narrative, so in this sense there is a decentring of normative patriarchal narration. The means by which this religious rapprochement is engaged is through the person of the Guru and the impact of his teachings: the Sikh tradition brings people together, and it is repeated throughout the work that the Guru tells people to be a good Hindu, as a Hindu, and to be a good Muslim, as a Muslim (although by the end, Sundari declares that while this is the case, it is also true that Guru Nanak has established a third way that itself should be followed) (Duggal 1989: 464). What matters is: "In his view, that one is good, who is a good human" 38 Teji's and Nasrin's friendship is the first (but one of many) prominent example of this portrayal of Muslims and Hindus; yet, when they become friends, out of their shared experience of sexual violence, people criticize them. There is no social space for the bridge they have built across their religious identities. They suffer social boycott and cannot use wells for washing or cooking, and no one will sell them food. They hear of Kartarpur, the community that gathered around Guru Nanak, and decide to go there: "Perhaps they will get justice from that court." 39 It is repeated throughout the text that "Baba Nanak is the king of the Fakirs, the Guru of the Hindus and Pir of the Muslims." ${ }^{40}$ When describing how the state troubled its populous, equality of experience is asserted, regardless of religious identity: "Innocent people were being troubled. Among them were Hindus, Muslims, and Sikhs alike." ${ }^{41}$ One of the most striking articulations of reconciliation between Hinduism and Islam is towards the end of the book. ${ }^{42}$ At one point, Sundari engages in conversation with a devout Muslim character who goes by the name Mughlani about

38 "unhān dī nazar vich chañgā uhī sī jihaṛā chañgā insān sî̀” (ibid.: 69). See also: Duggal 1989: 123, and elsewhere.

39 "us dargāh vicon̉ khabare insāf mile" (ibid.: 40).

40 "bābā nānak shāh fakīr, hindū dā gurū musalmān dā pīr" (ibid.: 81 and elsewhere).

41 "bekūsar lokān nūn preshan kītā jā rihā sī. inhān̉ vich hindū vī san, musalmān vī san, gursikh vī san" (ibid.: 294).

42 Duggal, Nānak nām ..., section 4, ch. 10 and 11, p. 420-426. 
the nature of Islam; listening to her description, Sundari says to herself: "This very thing is the teaching of the great Guru." ${ }^{43}$ At the end of the next chapter, Aman declares with a laugh that, based on the description of a Muslim, "Then I have also become a Muslim!" 44

This attempt at equivalence and sharing, however, is also incomplete and can be undermined by the text's own voice. For example, when Nasrin tells her attacker that she, too, is a Muslim and that he must at least marry her and treat her as a wife, he says: "The Muslims of India were all previously Hindu, and a Hindu never changes. Once a Hindu, always a Hindu." ${ }^{45}$ This is a theme in the book that relates back to the incident with Prito: Hindus might become Muslims, but they must retain a kind of affiliation as a Hindu. Differences between the two families of Aman's and Shaili's are sometimes stereotyped: the non-Muslims are humble and modest, the Muslims less so (ibid.: 414). When taken into account with reference to the opening of the text and the violence articulated in it, such features do stand in contrast to the conciliatory relationship staked out between Islam and Hinduism, and inclusivity of Sikhi, elsewhere in the text.

\section{A history for the present?}

Duggal's text is grounded in history: its opening sets the stage for this. He was overall also deeply concerned with the present. As I have described elsewhere, he was a vocal critic of the actions of both the Indian federal and Indian Punjabi state governments and of Khalistani militants in the 1980s and 1990s. He wrote in strong terms to articulate an alternative to both, and sought to intervene in the debates and divisions that were so contested in 1980s and 1990s Indian Punjab. ${ }^{46}$ Yet, we

43 “ihī te gurū mahārāj d̄i sikhiā hai" (ibid.: 421).

44 “injj tan் main் vī musalmān hoiā”" (ibid.: 426).

45 "hindī musalmān sāre pahile hindū san te hindū kadī nahīn badaldā. ik vār hiñdū, hameshā lā̄ hindū" (ibid.: 38-39).

46 See discussion of Duggal as a Progressive writer in Murphy 2018: 75-77 and Murphy, forthcoming b. 
see here some of the very same choices made that we see in Bhai Vir Singh's work, choices that Arti Minocha has argued were "instrumental in shaping the distinctive Khalsa identity with its history and gendered codes of behaviour, which the Singh Sabha reformers sought to consolidate” (Minocha 2019: 15). Duggal acts on one level to promote a vision of Sikh thought and practice as a form of rapprochement, a third path that moves beyond discord and which can provide a way forward, out of religious conflict. This resonates with aspects of Bhai Vir Singh's position as well, outlined above. At the same time, there are ways in which that very discord is inscribed in the work through portrayals of religious difference and conflict.

The past here is a ground through which the future could be reckoned with, but it also represents a kind of burden, a narrative that once engaged does not allow for movement outside. The work of both Bhai Vir Singh and Kartar Singh Duggal along these lines is thus ambivalent, in the end, about what the past represents, and what kind of present and future it offers. This is perhaps most strongly felt in the ways in which women and lower caste persons are engaged within the visions so produced: they do not challenge their logic, and act instead to support them. The violence against Prito/Nurjahān in Duggal's work exemplifies this. The future that is thus produced thus remains tied to the constraints of the past, as much as the seeds of a different future lie might lie nearby.

\section{References}

Chatterjee, P. 1993. The Nation and Its Fragments: Colonial and Postcolonial Histories. Princeton, NJ: Princeton University Press.

Dalmia, V. 1999. The Nationalization of Hindu Traditions: Bharatendu Harischandra and Nineteenth-Century Banaras. New Delhi: Oxford University Press. 
Dubrow, J. 2019. The Aesthetics of the Fragment: Progressivism and Literary Modernism in the Work of the All-India Progressive Writers' Association. In: Journal of Postcolonial Writing 55(5): 589-601. https://doi.org/10.1080/ 17449855.2019 .1635846$.

Duggal, K. S. 1989. Nānak nām chaṛhd̄̄ kalāa New Delhi: Navyug Publishers. Dulai, S. S. 1975. The Political Novel in Punjabi. In: Y. Malik and C. Lieberman (eds.). Politics and the Novel in India: Contributions to Asian Studies, Vol. VI. Leiden: Brill: 43-74.

Fair, C. 2010. The Novels of Bhai Vir Singh and the Imagination of Sikh Identity, Community, and Nation. In: D. R. Jakobsh (ed.) Sikhism and Women: History, Texts and Experience. New Delhi: Oxford University Press: 115-133.

Gill, T. S. (ed. and tr.) 2011a. Seven Plays on Sikh History by Sant Singh Sekhon. New Delhi: Sahitya Akademi.

Gill, T. S. 2011b. Introduction. In: Seven Plays on Sikh History by Sant Singh Sekhon. Ed. and tr. by T. S. Gill. New Delhi: Sahitya Akademi: ix-xxxiv. Gopal, P. 2005. Literary Radicalism in India: Gender, Nation, and the Transition to Independence. London: Routledge.

Grewal, J. S. 1990. Sikhs of the Punjab. Cambridge: Cambridge University Press. Guleria, J. S. 1985. Bhai Vir Singh: A Literary Portrait. Delhi: National Book Shop. Kaur Singh, N. G. 1993. The Feminine Principle in the Sikh Vision of the Transcendent. Cambridge: Cambridge University Press.

Kaviraj, S. 1998. The Unhappy Consciousness: Bankimchandra Chattopadhyay and the Formation of Nationalist Discourse in India. New Delhi: Oxford University Press.

Khosla, G. S. 1984. Bhai Vir Singh: An Analytical Study. New Delhi: Heritage Publishers.

Koselleck, R. 1985. Futures Past: On the Semantics of Historical Time. Cambridge, MA and London: MIT Press.

Macauliffe, M. A. 1909. The Sikh Religion: Its Gurus, Sacred Writings and Authors. Vols. 1-6. Oxford: Clarendon Press.

Malhotra, A. 2002. Gender, Caste, and Religious Identities: Restructuring Class in Colonial Punjab. New Delhi: Oxford University Press.

Malhotra, A. and Murphy, A. 2020. Introduction. In: Sikh Formations: Religion, Culture, Theory. Bhai Vir Singh (1872-1957): Rethinking Literary Modernity 
in Colonial Punjab, 16(1-2): 1-13. https://doi.org/10.1080/17448727.20 19.1674513.

Mandair, A. S. 2005. The Emergence of Modern 'Sikh Theology:' Reassessing the Passage of Ideas from Trumpp to Bhai Vir Singh. In: Bulletin of the School of Oriental and African Studies 68(2): 253-275.

McLeod, W. H. 2000. The Sikh Struggle in the Eighteenth Century and its Relevance for Today. In: W. H. McLeod (ed.) Exploring Sikhism: Aspects of Sikh Identity, Culture and Thought. New Delhi: Oxford University Press: 70-90.

Minocha, A. 2019. Bhai Vir Singh and the Public Sphere in Colonial Punjab. In: Sikh Formations: Religion, Culture, Theory, 16(1-2): 14-27. https:// doi.org/10.1080/17448727.2019.1674515.

Mir, F. 2010. The Social Space of Language: Vernacular Culture in British Colonial Punjab. Berkeley: University of California Press.

Mukherjee, M. 2006. Epic and Novel in India. In: F. Moretti (ed.). The Novel: Volume 1, History Geography, and Culture, Princeton: Princeton University Press: 596-631.

Murphy, A. 2011. Introduction. In: A. Murphy (ed.) Time, History, and the Religious Imaginary in South Asia. New York: Routledge: 1-11.

Murphy, A. 2012. The Materiality of the Past: History and Representation in Sikh Tradition. New York: Oxford University Press.

Murphy, A. 2017. Placing Max Arthur Macauliffe in Context(s): Sikh Historiographical Traditions and Colonial Forms of Knowledge. In: Journal of the Irish Society for the Academic Study of Religions, 4: 58-73. https://jisasr. files.wordpress.com/2017/03/placing-max-arthur-macauliffe-in-contextssikh-historiographical-traditions-and-colonial-forms-of-knowledge-pdf1. pdf, accessed on 27.12.2021.

Murphy, A. 2018. Writing Punjabi Across Borders. In: South Asian History and Culture, 9(1): 68-91.

Murphy, A. Forthcoming a. Beyond the Past: Poetry as a Notation of the Present.

Murphy, A. Forthcoming b. On the Possibility of the Secular in the Work of Kartar Singh Duggal.

Oesterheld, Ch. 2001. Nazir Ahmad and the Early Urdu Novel: Some Observations. In: Annual of Urdu Studies, 16: 27-42. 
Petievich, C. 2007. When Men Speak as Women: Vocal Masquerade in IndoMuslim Poetry. New Delhi: Oxford University Press.

Sekhon, S. S., and K. S. Duggal. 1992. A History of Punjabi Literature. New Delhi: Sahitya Akademi.

Singh, Raghbir. Forthcoming. Kartar Singh Duggal (1917-2012). In: Dictionnaire encyclopédique des littératures de l'Inde (Encyclopedic Dictionary of Indian Literatures. Paris: Classiques Garnier (Paris).

Sobti, H. S. 1987. Studies in Panjabi Fiction. Delhi: Eastern Book Linkers.

Vir Singh, B., 1968 [1918]. Satwant kaur. New Delhi: Bhai Vir Singh Sahitya Sadan.

Vir Singh, B. 2003 [1898]. Sundarī. New Delhi: Bhai Vir Singh Sahit Sadan. 